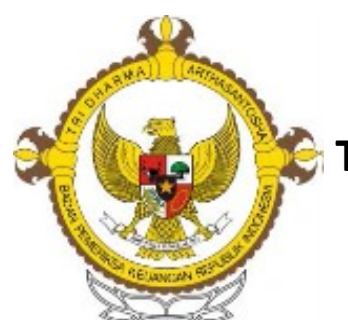

JURNAL

TATA KELOLA \& AKUNTABILITAS KEUANGAN NEGARA

Volume 5, Number 2, Jul-Dec 2019, 177-189

e-ISSN 2549-452X

p-ISSN 2460-3937

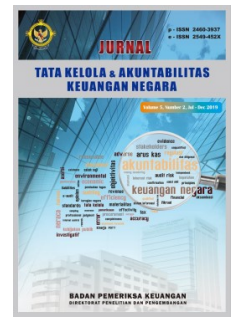

\title{
APPLICATION OF INVENTORY TURNOVER ANALYSIS ON INDONESIAN MINISTRY/AGENCY FINANCIAL STATEMENT
}

\author{
Laskar Rianto \\ Badan Pemeriksa Keuangan Republik Indonesia \\ laskar.rianto@bpk.go.id
}

\section{ABSTRACT}

Inventory turnover is a simple accounting analysis method seldom used by the user of Indonesian governmental organization's financial statement due to lack of accrual information in the past. The opportunity for the application of this analysis arrived in 2015 along with the implementation of accrual accounting basis by the Indonesian government. This study observes the Indonesian ministry/agency (MA) inventory management focusing on the inventory average flow time, during the 2017 and 2018 period. The study shows that among 86 MAs, 62 MAs have desired average flow time. The other 24 MAs have high average flow time with 12 of them also have unstable average flow time. While several MAs disclosed information related to their average flow time, most MAs did not. Thus, they failed to communicate their conditions to their stakeholders. The average flow time can be used as a starting point for the managers, auditors, and other stakeholders to further analyze government inventory management. Better inventory management can reduce costs and improve the government planning process. Therefore, the government may be capable of allocating their budget for other programs or activities to deliver higher value for the public.

\section{KEYWORDS:}

Inventory; turnover; accrual; disclosure; government

Permalink/DOI: 10.28986/jtaken.v5i2.377 


\section{INTRODUCTION}

Indonesian Government Accounting Standards (GAS) states that financial statements should present information to satisfy the needs of information of all user groups, which include but not limited to the public, representatives of the people, regulatory agencies, agency inspectors, and the government itself. One component of the financial statement is balance-sheet which describes the financial position of a reporting entity regarding its assets, liabilities, and equity at a specific date. The balance sheet covers government's assets, liabilities, and equity.

Aside from improving the transparency, government's balance sheet is expected to presents data that can be used by both management and stakeholders in managing public sector resources (Mellor, 1996). Balance sheet and other accrual-based financial statement components can create the linkage between assets and service delivery objectives. However, balance sheet information can be useful only if it is of good quality and if it, in fact, gets used. Warren (2013) states that there are some barriers in developing public sector balance sheets and then in using the balance sheet information for decision making and accountability purposes. One of the barriers is that government's balance sheet cannot be interpreted in the same manner as that of private sector. Warren (2013) also asserts that there are arguments that contest the value of government's balance sheets which can be characterized into three groups which are: distrust of balance sheet information, disinterest in balance sheet information, and the low value placed on balance sheet information.

Unlike the profit-oriented entity, the government balance sheet size and strength cannot be used to measure government success. In the public sector environment, a bigger balance sheet only means a bigger orga- nization. In the absence of a consensus of what the government size should be, there will be no target balance size aggregates. Warren (2013) further argues that the public sector balance sheet runs a risk of being considered a curiosity of novelty value only if balance sheet aggregates are not targeted as measures of performance. This argument leads to several questions including whether there are ways for government organizations to set any target for their balance sheet size and is there any way to increase the value of balance sheet information. This study is conducted in order to try to answer those questions. However, rather than try to take an overall picture of the balance sheet, this study will be focused on one component of the balance sheet, which is the inventory, by using inventory turnover analysis.

Inventory turnover analysis is one of the simplest analysis methods in accounting. It is generally used by financial statement users to get a glimpse of organizations' ability in managing their inventory. This method compares the organization's cost of goods sold with their inventory balance resulting in ratio value that can be compared with their past ratio or with other organizations' ratios. While management should be able to provide adequate amount of inventory support to maintain their service level (Morey, 1985), they should also keep a close track of the rate of inventory turnover to see if there are gradual reductions in the rate of turnover, which indicate that a corrective action may be required to eliminate excess inventory stocks (Bragg, 2005).

This analysis can also be used to measure the flow of business process of an organization due to having similar components with three key process performance that need to be assessed to measure business process flow: flow time, flow rate, and inventory (Anupindi, Chopra, Desmukh, Van Mieghem, \& Zemel, 2011). The flow time is 
the total time spent by a flow unit within a process, while the flow rate is the number of units that flow through a specific point in the process per unit time. In business process flow context, inventory is not defined merely as a material waiting to be processed or a product waiting to be sold but also has a broader meaning as a general flow unit. Therefore, it can encompass many things including customer, product, cash, orders, documents, supplies, and inventories. Those key performances are related through Little's law formula, which can be modified to become similar to inventory turnover analysis formula.

Albeit inventory turnover commonly used to analyze the financial statement, the study of its use in analyzing Indonesian government financial statement is very rare. This condition happens simply because, until 2014, the Indonesian government used cash toward accrual basis for their financial reporting; therefore, the government cannot present information about the utilization of their inventory. In 2015, the Indonesian government changed its accounting basis to full accrual basis, which enable them to produce more information about their financial activity in their report. This situation opens a window of opportunity for the user of the financial statement to employ more analytical tools to get a better understanding of the government's performance.

Since the government's main business activity is not selling goods nor services to their customers, their financial statements lack one component needed to compute the turnover, which is the cost of goods sold. In this situation, the Little's law comes as a solution. Little's law widely used to solve problems related to queue theory due to its flexibility (Little, 2011). Little's law formula relates average flow time, flow rate or throughput, and inventory. Thus, by identifying inventory and inventory throughput in the govern- ment's financial statement, the average flow time can be defined.

Governmental institutions' average flow rate and inventory can be widely varied from each other, owing to the diversity of their policies, activities, and operation scale. Indeed, the process to determine how much inventory to carry and balancing the need to keep inventory close enough to the customer to respond to demand and reduce transportation costs while trying to minimize investment in facilities and save warehousing costs is a complex one (American Productivity and Quality Center, 2005). Nevertheless, the institutions should have the same aim for their average flow time. A relatively low average flow time should be desired by all organizations because it allows an organization to be more responsive, reduce costs, easily develop new services, and indicate that the organization has operational excellence (Anupindi et al., 2011). Therefore, by comparing the flow time between institutions in the same period or comparing a certain institution flow time with their own from a different period may result in a glimpse of insight about the state and the change of their business flow. Additionally, since inventory is classified as current assets, it is not meant to be kept by the organization for longer than one year in normal condition. Accordingly, under normal circumstances, the average flow time should not exceed one year.

This study is aimed at learning the governmental institutions' average flow time, especially those of central government ministries/agencies (MA). This study also aims to learn whether MAs' disclose information related to their inventory turnover, especially for MAs with high average flow time.

\section{RESEARCH METHOD}

This study measured the business process flow of 86 MAs in Indonesia for the 2017- 
2018 period. It used MAs' financial statement data obtained from The Audit Board of the Republic of Indonesia (BPK RI) financial audit report for the respective period. For the quantitative analysis purpose, this study used three accounts, which are Inventory from the Balance Sheet and Inventory Expense and Goods-to-be-given-to-the public Expense from Operational Report for quantitative analysis. This study also used information from the Notes to Financial Statement for qualitative analysis.

$$
\mathrm{L}=\lambda \times \mathrm{W}
$$

$\mathrm{L}=$ Average number of items in a queuing system

$\lambda=$ Average arrival rate of an item in the system

$\mathrm{W}=$ Average waiting time of an item in the system

To measure inventory turnover (Kanet, 2004), the formula is modified to:

$$
\mathrm{I}=\mathrm{R} \times \mathrm{T} \text { or } \mathrm{T}=\mathrm{I} / \mathrm{R}
$$

$\mathrm{I}=$ Average Inventory

$\mathrm{R}=$ Throughput

$\mathrm{T}=$ Average Flow Time

Table 1 presents the operational definitions of the variables that will be used in the formula.
This study compares the MA's average flow time to each other in every period. Since inventory is classified as current assets and is expected to be realized immediately or held for use or sale within one year from the reporting date, the average flow time of the inventory under normal circumstances should be below or equal to one. This study will use $\mathrm{T}=1$ as a parameter to distinguish between the low average flow time MAs and the high average flow time MA. The parameter is established without considering MAs' inventory replenishment rate due to the lack of data about it.

This study also compares the average flow time of each MA to its score in a different period in order to measure the variation in each MAs' operation during the 2017-2018 period. By using the comparison, the MAs classified into three groups as shown in Figure 1.

In addition, this study conducts a qualitative analysis by using MA's notes to the financial statement. The qualitative analysis was conducted for several MAs in group 2 and group 3 that have a relatively high average flow time. Additionally, to better understand the result of the analysis, this study reviews several works of literature that are relevant to the result.

Table 1. Operational Variable Definition

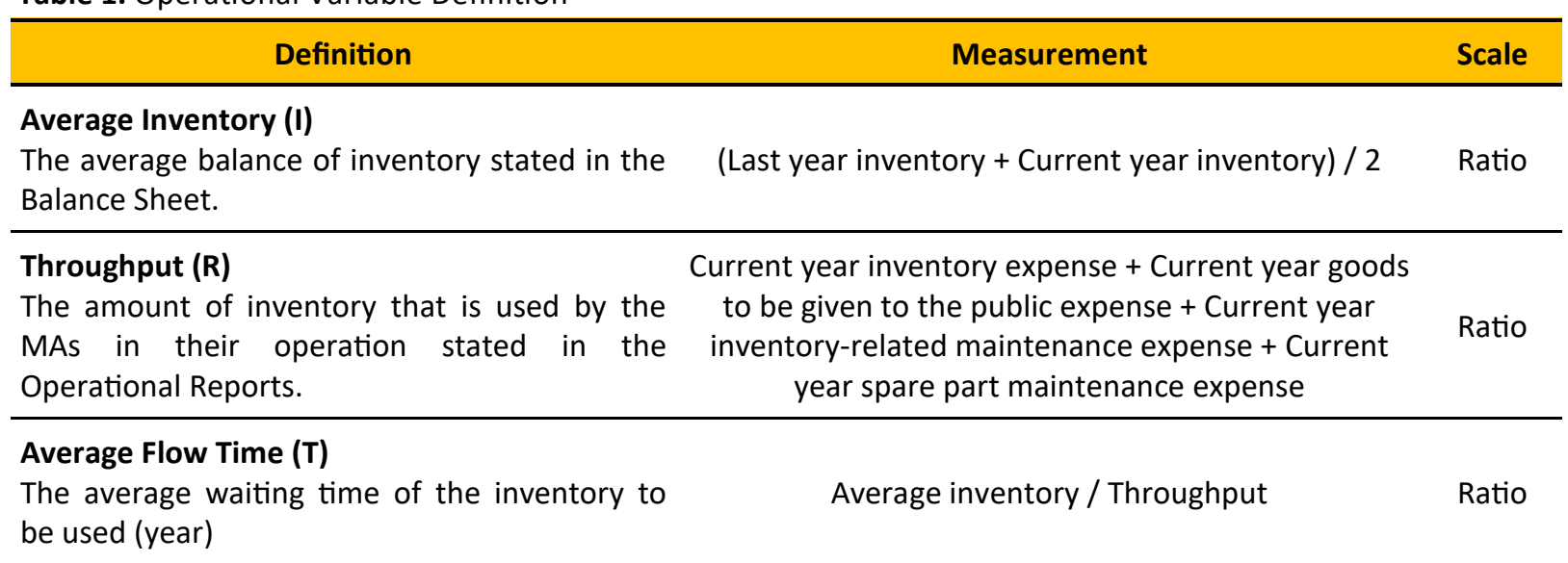

Source: Anupindi, et al. (2011) 
Figure 1. MAs Classification based on business process flow

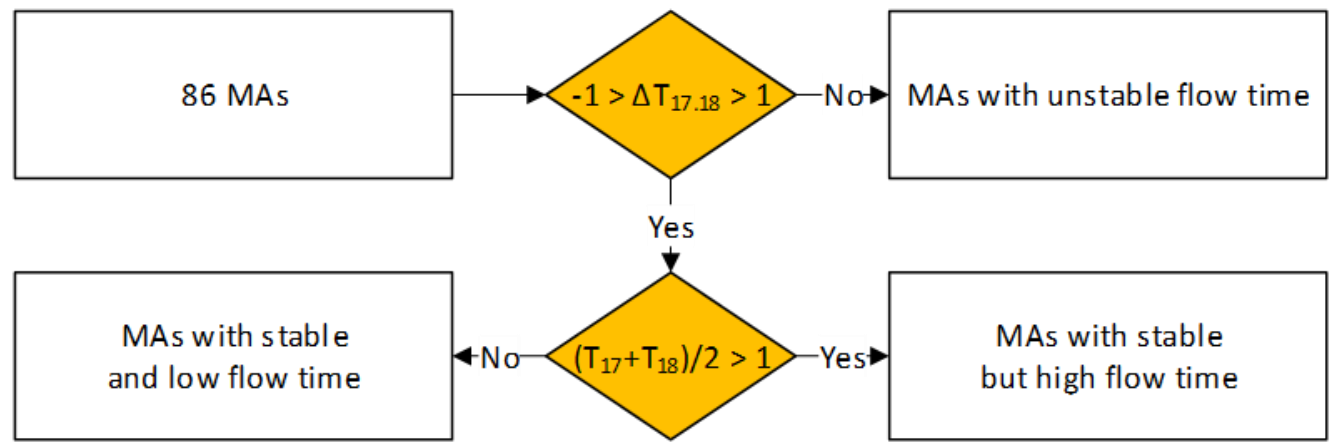

\section{RESULT AND DISCUSSION}

\section{MAs Average Flow Time}

This study uses descriptive statistics to briefly explain the average flow time of each MA and its variation during the 2017-2018 period as shown in Table 2.

Table 2 shows that the average flow time for all MAs is always above 1 year. However, the data is skewed to the right as the median and the third quartile of the data all below the average value. This condition happens because while most MAs have similar average flow time, which is relatively low, few MAs are having very high average flow time. As a low average flow time also means a high business flow, Table 3 reflects that at least half of the MA has high business flow.

At least $75 \%$ of the MAs do not have a considerable change in their inventory manage- ment, it is shown by a very small change in their average flow time between which is 0.25. However, there is an extreme gap between the median value with the minimum and maximum value, which indicates that there have been several MAs exposed to significant change in their inventory-related operation.

There are 62 MAs that have a relatively stable and low average flow time as shown in Appendix 1. Those MAs are able to maintain their business flow to match their inventory levels. It can also mean that those MAs can maintain their inventory level at an appropriate level so that it can be used in less than one-year time. The minimum average value for the year 2017 and 2018 of those MAs is 0.0044 , while the maximum value is 0.9340 .

There are 12 MAs that have a relatively stable but high average flow time as shown in Appendix 2. Those MAs maintain a high

Table 2. Descriptive Statistics

\begin{tabular}{cccccccc}
\hline Variables & Mean & Std. Dev & Minimum & Q1 & Median & Q2 & Maximum \\
\hline $\mathrm{T}_{17}$ & 2.187 & 9.209 & 0.005 & 0.233 & 0.458 & 0.984 & 83.856 \\
\hline $\mathrm{T}_{18}$ & 2.4262 & 7.867 & 0.004 & 0.266 & 0.497 & 1.285 & 68.104 \\
\hline \multirow{2}{*}{$\Delta \mathrm{T}_{17.18}$} & 0.21 & 10.87 & -82.74 & -0.04 & 0.03 & 0.25 & 52.32 \\
\hline
\end{tabular}

Notes:

$\mathrm{T}_{17} \quad$ = Average flow time in the year 2017

$\mathrm{T}_{18} \quad$ = Average flow time in the year 2018

$\Delta \mathrm{T}_{17.18}=$ Deviation of average flow time between the year 2017 and the year 2018 
amount of inventory in their possession with no observable effort to change its inventory management. MA with the highest flow time in this category is MA 083 with average flow time in 2017 and 2018 are 15.219 and 15.425 respectively. This figure can be interpreted as even if the agency does not procure additional inventory, they can use their current inventory for fifteen years of operation. The second and third positions in this category are MA 022 and MA 006 having average flow time in 2018 as high as 7.6389 and 3.4842 respectively.

There are 12 MAs that have an unstable business process flow as shown in Appendix 3 . The flow time deviation between 2017 and 2018 range from -82.7365 to 52.3126 . While negative deviation values indicate an improvement in inventory management, positive values increase inventory-related risk. MA 055 has the highest deviation flow time, which is 52.3216. The deviation significantly increases the already high flow time of 15.7826 to 68.1041 and become MA with the highest average flow time among all MAs. MA 090 and MA 119 has the second and third highest deviation with 19.2105 and 12.7166 respectively.

\section{The Average Flow Time as a Symptom}

High average flow time serves as a symptom of problems that may lie within organizations. Anupindi, et al. (2011) advocate that flow time is an important integrative measure of overall process performance. Thus, a sudden significant change in average flow time may indicate a change in performance. This condition best reflected in the information that is disclosed by MA 055 and the MA 090 in their financial statements.

The inventory amount of MA 055's disclosure rose sharply because they act as a Millennium Challenge Corporation Grant Administrator. Therefore, they record the goods that are delivered by the donor in their balance sheet before the goods are distributed to the intended benefactors, increasing their average flow time. The sudden increase in their inventory are not followed by the same level of increase in their inventory-related expense, thus shoot their average flow time up.

MA 090 inventory received inventory transfer from various co-administration task force units (unit kerja tugas pembantuan). The forms of the inventory that they received are 561 market buildings, 36 machines and equipment, and 4 other assets. The transfer resulting in the increasing inventory in 2018 significantly by 105.28 times from their previous year's inventory amount. MA 055 and MA 090 sudden increase in their average flow time and their disclosures in their financial report inform their financial report users that in 2018 they received an extraordinary burden in their operation which should be addressed by the management. Management should allocate more resources to support the business process related to their inventory management to adapt to this new challenge.

MA 006 and MA 093 have a somewhat similar problem with those that are faced by the MA 055 and the MA 090 in terms of their lack of control over their inventory intake. Most of the MA 006 and MA 093's inventory are confiscated goods that are gained by a legally binding court decision. Hence, their management does not have meaningful control over the majority of their inventory input. Consequently, the inventories were accumulated to the point that it formed the greater part of their total inventory. In the MA 006's case, the confiscated goods form $98.88 \%$ of their total inventory. MA 006 average flow time is increasing albeit relatively insignificant (0,3792), while MA 093 has a higher increase in their average flow time (1.8095). However, management should be 
able to properly adjust their business process that is related to their inventory throughput. Failure in adjusting their inventory throughput will result in excess inventory.

The problem in matching business process related to inventory input and those that related to business output not only occurred within an organization that has a lack of control over their inventory input such as the four aforementioned organization, but also within the organization that has a sufficient control over the input such as MA 042. MA 042 disclosed that their high inventory value caused by fixed assets that are going to be given to universities, which is presented as inventory in their balance sheet. They also disclose the nature and the recipient of the goods. However, their high average flow time indicates that they cannot distribute the goods to their recipients on time. Their notes to financial statement state that out of $1,333.64$ billion of goods that should be transferred to universities, the ministry only transfers 38,92 billion (2.92\%) out of it, while at the same time add 704.45 billion into it to further increase their amount of inventory.

High average flow time can also be interpreted as a symptom of excess in inventory. Indeed, an organization having a high average flow time may not necessarily having an excess inventory, since for determining the excess inventory we should not only consider the excess of organization's working inventory represented by their throughput, but also the excess their safety inventory, anticipation inventory, work-in-process inventory, and decoupling inventory (Toelle \& Tersine, 1989).

Several organizations are known for have been maintaining a significant amount of safety inventory and anticipation inventory in their normal operation, such as those that are related to security, health, and social net, also food safety. Nevertheless, most if not all MAs do not disclose their policies regarding those inventories, thus prohibiting us from having an obvious boundary for excess inventory. Despite this limitation, the very high flow time that exists in some organizations is a sign that they are holding much more inventory than what they need such as the BIG. Since BIG average inventory constantly higher than their throughput, most of their inventory is a slow-moving type that will not be consumed within 12 months.

Aside from serving as a symptom for a change in performance and excess inventory, a high flow time can also serve as a symptom for the existence of material weaknesses in internal control (Feng, Li, McVay, \& Skaife, 2015). Feng et al. found that an organization that has inventory-related material weaknesses in internal control are more likely to experience the shortage or excess of inventory and to have a higher rate of inventory obsolescence. Nevertheless, the research that is conducted in this study does not have adequate information from the existing financial statement to support this statement.

\section{Possible Corrective Action}

To acquire the desired average flow time, several corrective actions may be undertaken by the management of the MAs. The first possible course of action is to try to find and promote process innovation as it will have a long-lasting effect on inventory turnover (Lee, Zhou, \& Hsu, 2015). The process innovation can reduce the average flow time if it can fulfill at least two requirements. First, innovation should be able to improve flexibility, responsiveness, coordination, and team-oriented work at an operational level. Second, it should change the way that entity share information and knowledge within or even across the organization. The process innovation in the MAs should be stressed on 
linking the operational units that managing inventory influx with the unit the managing inventory disbursement. If the majority of MAs inventory is goods to be sold or distributed to the public or other parties, the management should also maintain a connection with the intended beneficiaries of the inventory. This action is also in line with those that are proposed by Altug and Muharremoglu in 2011 and APQC in 2005. Altug and Muharremoglu (2011) advertise the importance of collaboration between demand and supply information. APQC (2005) highlight the importance of deliberate partnerships with internal and external suppliers to significantly increase replenishment speed and efficiency. APQC (2005) also advocates for the integration between suppliers' processes and internal processes to achieve common goals.

The second possible corrective action is by addressing the excess inventory. The best scenario is by preventing excess inventory from building up. It can be done by giving attention to some frequent causes which are: forecasting errors, inventory record inaccuracies, inadequate planning and execution systems, long and variable lead time, obsolescence, and distribution channel adjustment (Toelle \& Tersine, 1989). However, when the excess inventory is already built up, liquidation may be needed to deplete the amount of inventory. The net benefit of liquidating the excess inventory will come in forms of salvage revenue plus holding cost savings. As Toelle and Tersine (1989) explained, the terms liquidating not only encompass selling but also redistributing the inventory to a location where there is demand. If this corrective action supported by an established process innovation, redistribution can also involve other MAs. Nevertheless, when the organization decides to use the liquidation method, it should also consider liquidation cost since it is possible for an item to have zero, or even negative, sal- vage value.

Recent studies have found several models that can be used to increase MA's inventory turnover for organizations that are required to maintain a high number of buffer stock. While a low inventory level is a general indicator of efficient organizational operation, several organizations cannot recklessly reduce their inventory because they are required to maintain a certain amount of inventory as part of their operational readiness. The best example of this condition is MAs that related to disaster preparedness such as MA 103, MA 107, and MA 24. Those MAs should weight the cost related to inventory with the quality of their service delivery, especially in an emergency. In this kind of situation, disaster management capabilities (DMC) may be well suited to be adopted by those organizations (Kunz, Reiner, \& Gold, 2014). The reasoning behind the adoption suitability is, while pre-positioning physical inventory in the warehouse before disaster leads to high demand satisfaction from its beneficiaries, it also involves a high cost. The DMC model may help an organization to reduce their idle inventory without sacrificing their readiness nor their level of service. The second model is by applying a preventive maintenance policy that can be applied by organizations that are required to hold inventory in a large size for maintenance purposes (Poppe, Basten, Boute, \& Lambrecht, 2017).

\section{Limitation}

The value of inventory presented in the financial statement may not reflect the whole inventory in MAs possession. An example of this condition can be found in the information disclosed by the MA 006 in their financial statement. The confiscated goods that are presented in the financial statement of MA 006 are only those that have gone through the valuation process, the other confiscated goods not valued yet are not pre- 
sented in the balance sheet. Owing to this fact, their real average flow time in 2018 should be higher than 3.4842 .

The high average flow time that exists in several MAs may happen intentionally, where the existed condition happens as a result of the implementation of policies or regulations. The policies may include but not limited to buffer stock, emergency stock, procurement, utilization, and transfer policy. However, since this study only considers the information obtained from the financial statement, the policies or regulations that are not disclosed within the financial statement are omitted.

Inventory management in public and private sector have a different perspective. In the private sector, inventory holding cost kept organization away from their goal, which is profit, thus it should be kept as low as possible. In the public sector, inventory holding cost does not have a distinct relationship with the government's goal, which is to provide service to the public (Bondy, 1991). In a few cases, a high holding cost, a consequence of a high amount of inventory being maintained, can also serve as an indication of performance. A clear example of this situation is in the military where inventory in the warehouse is the service, or the public goods, as it provides an essential source of deterrence. In this context, inventory holding cost makes no sense. Therefore, in this situation, inventory turnover analysis becomes irrelevant.

\section{CONCLUSION}

The majority of the MAs have a relatively low average flow time; however, 24 MAs have a high average flow time. While a low average flow time cannot serve as an indicator of problem-free inventory management, more attention should be given to MAs with high average flow time. The high average flow time is a symptom of the problem in organization inventory management.
The qualitative information that is disclosed by several MAs in their notes to the financial statement can be used to pinpoint the real inventory-related problem. After identifying the real problem, and after considering the organization's business process, a relevant corrective action may be assigned to address the problem. However, MAs that provide adequate relevant information that can help to explain their average flow time is the minority of the set.

The stakeholders, including policymakers, should inquire proper and adequate disclosures that are rich in meaningful information since it can help them to understand the organization's condition better. Accordingly, the management should provide it since it helps them to communicate their condition and policies to their stakeholders. However, the government's accountants have to ensure that they do not barrage the stakeholders with meaningless information in their disclosures. The GAS has already mentioned that relevancy and reliability are two of the qualitative characteristics that become prerequisite for the financial statement to fulfill its purposes. For this reason, there are challenges for accounting standards setters to require information where it provides most value and eliminate disclosures that are mere compliance costs; and for the accountants to disclose information that has feedback value, to correct or confirms previous knowledge or expectations, and predictive value, to allow a more honed assessment to be made about the future (Warren, 2013).

By considering its limitation, the inventory turnover analysis may not be sufficient in analyzing MAs inventory management. Rather, the analysis can be used as a short and simple initial step that can be used by management or stakeholders as a starting point for a further in-depth and detailed examination that involves other sources of infor- 
mation and considerations.

This study shows that ratio analysis, including inventory turnover analysis, can be developed and conducted over Indonesian government institutions' financial statements to measure one or more aspects of the government's financial-related performance. A comparison of financial ratios among central governmental institutions can be used to set a benchmark for governmental institution balance sheet size. Hence, the institutions can use the benchmark as a guideline for making better financial management decisions, using more precise information than previously, so that they can utilize and distribute social resources in a better way.

\section{REFERENCES}

Altug, M. S., \& Muharremoglu, A. (2011). Inventory management with advanced supply information. International Journal of Production Economics, 129, 302-313.

American Productivity and Quality Center. (2005). Inventory optimization: $\mathrm{Ba}-$ lancing the asset versus service tradeoff. Houston: APQC.

Anupindi, R., Chopra, S., Desmukh, S. D., Van Mieghem, J. A., \& Zemel, E. (2011). Managing business process flow: Principles of operational management, Third edition. New Jersey: Pearson Education, Inc.

Bondy, H. (1991). Inventory carrying cost in government. Canadian Public Administration, 34(3), 527-530.

Bragg, S. M. (2005). Inventory accounting a comprehensive guide. New Jersey: John Wiley \& Sons, Inc.

Feng, M., Li, C., McVay, S. E., \& Skaife, H. (2015). Does ineffective internal control over financial reporting affect a firm's operations? Evidence from firms' inventory management. The Accounting Review, 9o(2), 529-557.
Government Accounting Standard Committee. (2019). Government accounting standards. Jakarta.

Kanet, J. J. (2004). Mean flowtime and inventory in production systems: A finite time analogue to Little's Law. International Journal of Production Economics, 91, 37-46.

Kunz, N., Reiner, G., \& Gold, S. (2014). Investing in disaster management capabilities versus pre-positioning inventory: A new approach to disaster preparedness. International Journal of Production Economics, 157, 261-272.

Lee, H.-H., Zhou, J., \& Hsu, P.-H. (2015). The role of innovation in inventory turnover performance. Decision Support System, 76, 35-44.

Little, J. D. (2011). Little's Law as viewed on its 5oth anniversary. Operations Research, 536-549.

Mellor, T. (1996). Why government should produce Balance Sheet. Australian Journal of Public Administration, 55 (1), 78-81.

Morey, R. C. (1985). Estimating service level impact from changes in cycle count, buffer stock, or corrective action. Journal of Operation Management, 5(4), 411-418.

Poppe, J., Basten, R. J., Boute, R. N., \& Lambrecht, M. R. (2017). Numerical study of inventory management under various maintenance. Reliability Engineering and System Safety, 168, 262-273.

Toelle, R. A., \& Tersine, R. J. (1989). Excess inventory: Financial asset or operational liability? Production and Inventory Management Journal, 3O(4), 32-25.

Warren, K. (2013). The development and use of public sector balance sheets. In R. Allen, R. Hemming, \& B. H. Potter (Eds.), The International Handbook of Public Financial Management (pp. 558-572). New York: Palgrave Macmillan. 


\section{APPENDICES}

Appendix 1. Ministry/agency with a relatively stable and low average flow time

\begin{tabular}{|c|c|c|c|c|}
\hline \multirow{2}{*}{ Ministry/Agency Budget Section Code } & \multicolumn{4}{|c|}{ Average Flow Time } \\
\hline & 2017 & 2018 & Mean & Deviation \\
\hline 001 & 0.1785 & 0.2487 & 0.2136 & 0.0702 \\
\hline 002 & 0.4014 & 0.5126 & 0.4570 & 0.1112 \\
\hline 004 & 0.3152 & 0.3367 & 0.3259 & 0.0215 \\
\hline 005 & 0.1886 & 0.2356 & 0.2121 & 0.0470 \\
\hline 010 & 0.8384 & 0.4816 & 0.6600 & -0.3568 \\
\hline 011 & 0.6017 & 0.7064 & 0.6541 & 0.1047 \\
\hline 013 & 1.0746 & 0.7172 & 0.8959 & -0.3573 \\
\hline 015 & 0.4615 & 0.4212 & 0.4413 & -0.0403 \\
\hline 018 & 0.0405 & 0.1293 & 0.0849 & 0.0888 \\
\hline 023 & 0.0922 & 0.1040 & 0.0981 & 0.0118 \\
\hline 024 & 0.3041 & 1.1648 & 0.7345 & 0.8607 \\
\hline 025 & 0.0731 & 0.0671 & 0.0701 & -0.0060 \\
\hline 026 & 0.0388 & 0.4873 & 0.2631 & 0.4485 \\
\hline 032 & 0.4283 & 0.3194 & 0.3739 & -0.1088 \\
\hline 033 & 0.5016 & 0.6148 & 0.5582 & 0.1132 \\
\hline 034 & 0.0047 & 0.0041 & 0.0044 & -0.0006 \\
\hline 035 & 0.1322 & 0.1482 & 0.1402 & 0.0160 \\
\hline 036 & 0.2175 & 0.2326 & 0.2251 & 0.0151 \\
\hline 040 & 0.4585 & 0.3698 & 0.4141 & -0.0887 \\
\hline 041 & 0.3467 & 0.4670 & 0.4069 & 0.1203 \\
\hline 044 & 0.0457 & 0.9229 & 0.4843 & 0.8772 \\
\hline 047 & 0.4530 & 0.2565 & 0.3547 & -0.1965 \\
\hline 048 & 0.2291 & 0.2631 & 0.2461 & 0.0340 \\
\hline 050 & 0.4399 & 1.0371 & 0.7385 & 0.5972 \\
\hline 051 & 0.6252 & 0.4098 & 0.5175 & -0.2155 \\
\hline 052 & 0.0062 & 0.0140 & 0.0101 & 0.0078 \\
\hline 054 & 0.5691 & 0.4599 & 0.5145 & -0.1093 \\
\hline 056 & 0.1411 & 0.1150 & 0.1280 & -0.0260 \\
\hline 057 & 0.1350 & 0.1510 & 0.1430 & 0.0160 \\
\hline 059 & 0.3565 & 0.3459 & 0.3512 & -0.0106 \\
\hline 060 & 0.8880 & 0.9800 & 0.9340 & 0.0920 \\
\hline 064 & 0.2857 & 0.3077 & 0.2967 & 0.0220 \\
\hline 065 & 0.4703 & 0.3095 & 0.3899 & -0.1608 \\
\hline 066 & 0.7872 & 0.8139 & 0.8005 & 0.0267 \\
\hline 067 & 0.4624 & 0.5987 & 0.5305 & 0.1363 \\
\hline 074 & 0.1592 & 0.2752 & 0.2172 & 0.1160 \\
\hline 075 & 0.5956 & 0.7233 & 0.6594 & 0.1278 \\
\hline 077 & 0.5367 & 0.3303 & 0.4335 & -0.2064 \\
\hline 078 & 0.3417 & 0.3816 & 0.3617 & 0.0400 \\
\hline 081 & 0.2904 & 0.3785 & 0.3345 & 0.0881 \\
\hline
\end{tabular}


JURNAL TATA KELOLA \& AKUNTABILITAS KEUANGAN NEGARA, Vol. 5, No. 2, 2019: 177-189

\begin{tabular}{|c|c|c|c|c|}
\hline \multirow{2}{*}{ Ministry/Agency Budget Section Code } & \multicolumn{4}{|c|}{ Average Flow Time } \\
\hline & 2017 & 2018 & Mean & Deviation \\
\hline 084 & 0.0803 & 0.0942 & 0.0873 & 0.0139 \\
\hline 085 & 0.5909 & 0.7100 & 0.6504 & 0.1191 \\
\hline 086 & 0.5389 & 0.5574 & 0.5481 & 0.0186 \\
\hline 087 & 0.3329 & 0.3133 & 0.3231 & -0.0196 \\
\hline 088 & 0.5762 & 0.6044 & 0.5903 & 0.0282 \\
\hline 089 & 0.4277 & 0.4368 & 0.4323 & 0.0091 \\
\hline 092 & 0.2433 & 0.0901 & 0.1667 & -0.1532 \\
\hline 095 & 0.1984 & 0.1440 & 0.1712 & -0.0545 \\
\hline 100 & 0.4416 & 0.2504 & 0.3460 & -0.1912 \\
\hline 103 & 0.8088 & 1.0484 & 0.9286 & 0.2395 \\
\hline 106 & 0.9354 & 0.5589 & 0.7472 & -0.3765 \\
\hline 108 & 0.1058 & 0.1172 & 0.1115 & 0.0113 \\
\hline 110 & 0.3701 & 0.3492 & 0.3597 & -0.0209 \\
\hline 112 & 0.1400 & 1.0509 & 0.5955 & 0.9109 \\
\hline 113 & 0.2574 & 0.5073 & 0.3823 & 0.2499 \\
\hline 114 & 0.3624 & 0.3243 & 0.3433 & -0.0380 \\
\hline 115 & 0.1055 & 0.0519 & 0.0787 & -0.0536 \\
\hline 116 & 0.3420 & 0.3606 & 0.3513 & 0.0186 \\
\hline 117 & 0.4934 & 0.2545 & 0.3739 & -0.2389 \\
\hline 118 & 0.6556 & 0.6198 & 0.6377 & -0.0358 \\
\hline 120 & 0.0936 & 0.1683 & 0.1310 & 0.0747 \\
\hline 121 & 0.0172 & 0.0180 & 0.0176 & 0.0008 \\
\hline
\end{tabular}

Appendix 2. Ministry/agency with a relatively stable but high average flow time

\begin{tabular}{ccccc}
\hline \multirow{2}{*}{ Ministry/Agency Budget Section Code } & \multicolumn{4}{c}{ Average Flow Time } \\
\cline { 2 - 5 } & $\mathbf{2 0 1 7}$ & $\mathbf{2 0 1 8}$ & Mean & Deviation \\
\hline 006 & 3.105 & 3.4842 & 3.2946 & 0.3792 \\
\hline 019 & 1.9966 & 1.3545 & 1.6756 & -0.642 \\
\hline 022 & 7.9249 & 7.6389 & 7.7819 & -0.286 \\
\hline 029 & 1.2298 & 1.8644 & 1.5471 & 0.6347 \\
\hline 042 & 1.9697 & 2.2617 & 2.1157 & 0.2919 \\
\hline 063 & 1.1176 & 1.6285 & 1.3731 & 0.5109 \\
\hline 068 & 1.3144 & 1.3596 & 1.337 & 0.0452 \\
\hline 076 & 1.3659 & 0.7829 & 1.0744 & -0.583 \\
\hline 079 & 0.8907 & 1.3246 & 1.1076 & 0.4339 \\
\hline 080 & 1.4544 & 1.7022 & 1.5783 & 0.2478 \\
\hline 083 & 15.219 & 15.425 & 15.322 & 0.2065 \\
\hline 107 & 2.6611 & 2.1666 & 2.4139 & -0.495 \\
\hline
\end{tabular}


APPLICATION OF INVENTORY TUNOVER ANALYSIS ON ...

Laskar Rianto

Appendix 3. Ministry/agency with a relatively unstable and high average flow time

\begin{tabular}{crrrr}
\hline \multirow{2}{*}{ Ministry/Agency Budget Section Code } & \multicolumn{4}{c}{ Average Time Flow } \\
\cline { 2 - 5 } & \multicolumn{1}{c}{$\mathbf{2 0 1 7}$} & \multicolumn{1}{c}{$\mathbf{2 0 1 8}$} & \multicolumn{1}{c}{ Mean } & Deviation \\
\hline 007 & 4.3999 & 6.7885 & 5.5942 & 2.3886 \\
\hline 012 & 2.9892 & 4.7397 & 3.8645 & 1.7505 \\
\hline 020 & 0.4409 & 2.0165 & 1.2287 & 1.5756 \\
\hline 027 & 3.5680 & 6.5683 & 5.0681 & 3.0002 \\
\hline 055 & 15.7826 & 68.1041 & 41.9434 & 52.3216 \\
\hline 082 & 2.8479 & 3.9105 & 3.3792 & 1.0626 \\
\hline 090 & 0.3409 & 19.5514 & 9.9462 & 19.2105 \\
\hline 093 & 3.2816 & 5.0912 & 4.1864 & 1.8095 \\
\hline 104 & 2.7673 & 4.4003 & 3.5838 & 1.6330 \\
\hline 109 & 83.8556 & 1.1191 & 42.4874 & -82.7365 \\
\hline 111 & 0.9997 & 3.4631 & 2.2314 & 2.4634 \\
\hline 119 & 3.7201 & 16.4367 & 10.0784 & 12.7166 \\
\hline
\end{tabular}

Selected and Revised Papers from The International Conference of State Finance and Accountabillity (InCSFA 2019) (Badan Pemeriksa Keuangan Republik Indonesia, by $10^{\text {th }}$ October 2019) after peer-reviewed by Organizing Committee of InCSFA and Peer-reviewers of Jurnal Tata Kelola \& Akuntabilitas Keuangan Negara 


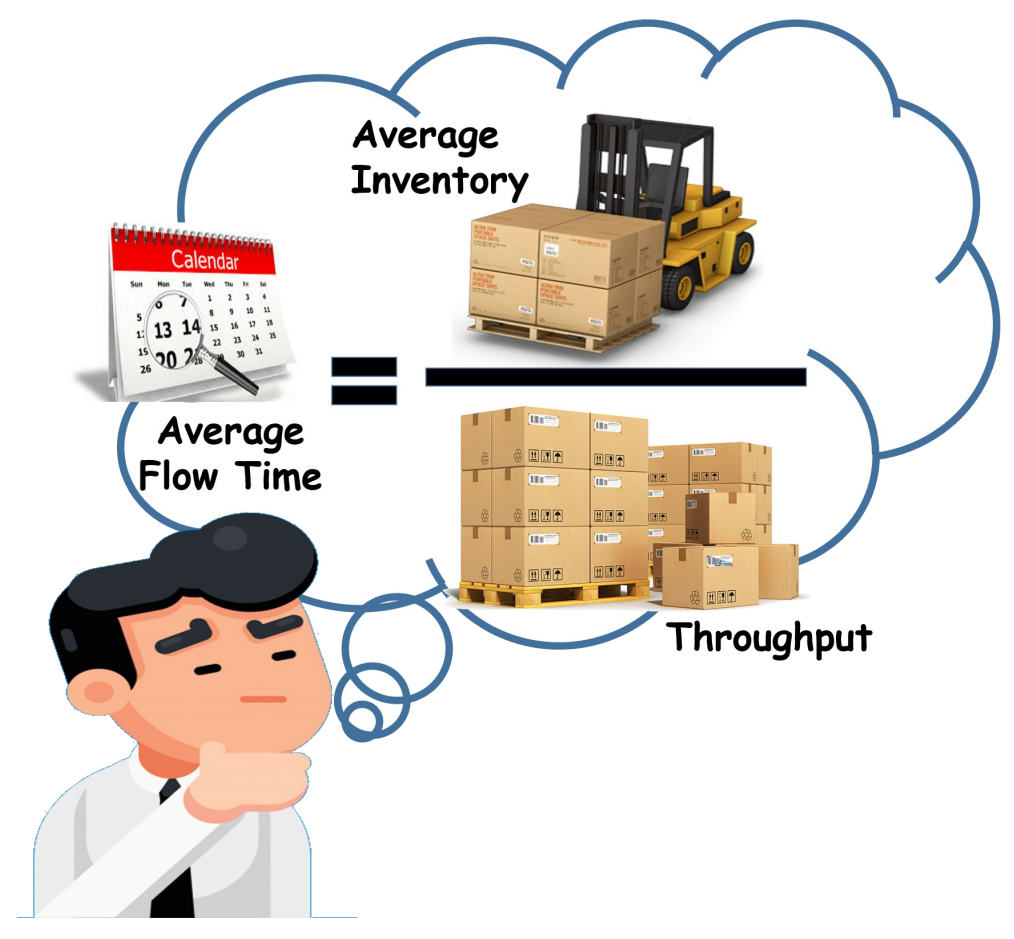

